\title{
Strategi Pengembangan Profesionalisme Tenaga Pendidik di Madrasah
}

\author{
Wakhidati Nurrohmah Putri \\ Institut Agama Islam Negeri (IAIN) Salatiga \\ wakhidputri@gmail.com \\ Muhammad Aji Nugroho \\ Program Doktor UIN Walisongo Semarang \\ khoira2013@gmail.com \\ DOI: 10.18326/mudarrisa.v8i2.313-340
}

\begin{abstract}
Abstrak
Penelitian ini bertujuan untuk mengetahui strategi pengembangan profesionalisme tenaga pendidik di madrasah, penelitian ini adalah penelitan diskriptif kualitatif yang mencoba mengeksplorasi makna profesionalisme pendidik sebagai langkah mengembangkan mutu madrasah dengan menyesuaikan tujuan pendidikan. Dalam penelitian ini melihat guru sebagai kunci atau figur sentral dalam penyelenggaraan pendidikan atau peningkatan mutu pendidikan madrasah, yang memiliki posisi yang sangat strategis bagi seluruh upaya reformasi pendidikan yang berorientasi pada pencapaian kualitas murid dan persekolahan. Hal ini disebabkan, pada era globalisasi yang makin masif dan ekstensif ini, tanpa didukung oleh sumber daya manusia (SDM) yang berkualitas, suatu Negara akan tertinggal jauh. Tolak ukur pengembangan Sumber Daya Manusia menjadi prioritas yang sangat urgen dalam pembentukan kepribadian bagi setiap Negara. Dalam menghadapi persaingan sosial, ekonomi, tekhnologi, dan kemanusiaan, semakin bereskalasi secara massif, Maka persyaratan kemampuan yang diperlukan orang untuk melakukan pekerjaan semakin meningkat, dimulai dari pengetahuan, ketrampilan, dan sikap. Dari sinilah, tuntutan akan perlunya profesionalisme dalam bekerja bagi seorang tenaga pendidik sangat
\end{abstract}


dibutuhkan untuk memacu keberhasilan peserta didiknya. Betapapun baiknya kurikulum yang dirancang para ahli dengan ketersediaan peralatan dan biaya yang cukup sesuai dengan pendidikan, namun pada akhirnya keberhasilan pendidikan secara professional terletak ditangan guru.

This study aims to determine the development strategy of the professionalism of educators at the school, this research is descriptive qualitative research that tries to explore the meaning of professionalism of teachers as a step to develop the quality of islamic education by adjusting educational purposes. In this study, the teacher is a key or central figure in education or improving the quality of Islamic education, which has a very strategic position for all reforms oriented educational attainment of pupils and the quality of schooling. This is because, in the era of globalization, is more massive and this extensive, unsupported by human resources quality, A State would be left far behind. The measurement of development human resources is a priority that is extremely vital in the formation of personality to any State. In the face of social, economics, technology competition, and humanity, increasingly escalated massively, then the requirements of the capabilities required to do the work increased, starting from the knowledge, skills and attitudes. So "professionalism in the works" for the educators is needed to spur the success of learners. Although well-designed curriculum was made by experts with complete facilities, but the success of professional education lies in the hands of teachers.

Kata Kunci: pengembangan SDM, profesionalisme, tenaga pendidik

\section{Pendahuluan}

Pendidikan di Indonesia banyak mengalami persoalan, antara lain yang menonjol saat ini adalah mengenai mutu pendidikan, manajemen pendidikan, dan dana pendidikan yang dirasakan masih kurang, 
mengingat negara ini begitu luas ditambah lagi dengan banyaknya jumlah penduduk. Sehingga kesulitan untuk menyesuaikan dengan suasana baru yang ditimbulkan oleh kemajuan ilmu pengetahuan dan tekhnologi modern (Nasution, 1991:11). Sehingga tujuan utama pendidikan untuk dapat mencerdaskan kehidupan bangsa untuk membentuk manusia seutuhnya yaitu beriman, bertakwa kepada Tuhan Yang Maha Esa, berakhlak mulia, sehat, cakap, kreatif, mandiri, dan bertanggung jawab, tidak seperti apa yang diharapkan sebagaimana yang tertera dalam Undang-Undang Sistem Pendidikan (Depdiknas, 2003:3).

Dalam dunia pendidikan guru merupakan figur sentral dalam penyelenggaraan pendidikan, karena guru adalah sosok yang sangat diperlukan untuk memacu keberhasilan peserta didiknya. Betapapun baiknya kurikulum yang dirancang para ahli dengan ketersediaan peralatan dan biaya yang cukup sesuai dengan pendidikan, namun pada akhirnya keberhasilan pendidikan secara professional terletak ditangan guru. Maka keberhasilan pendidikan pada siswa disekolah tertentu sangat tergantung pada pertanggung jawaban guru dalam melaksanakan tugasnya, sebagai faktor kunci terhadap seluruh upaya yang dilakukan dalam kerangka peningkatan mutu pendidikan tersebut. (Usman, 1992:3).

Guru merupakan kunci dalam peningkatan mutu pendidikan, dan guru disini berada pada posisi yang sangat strategis bagi seluruh upaya reformasi pendidikan yang berorientasi pada pencapaian kualitas murid dan persekolahan. Adapun upaya yang dilakukan dalam peningkatan kualitas pendidikan dalam sebuah sistem persekolahan akan menjadi tidak berarti jika tidak disertai oleh adanya guru yang professional 
(Surya, 2000:1). Oleh karena itu dalam mengembangkan guru yang professional, maka seorang guru tidak hanya dituntut untuk mempertebal kemampuan secara disipliner, tetapi lebih dari itu dituntut untuk mempunyai kualitas yang interdisipliner. Harus ada pendekatan bersama untuk semua dan pendekatan berbeda untuk disiplin spesialis yang berbeda (Ashrof, 1993:5). Hal ini diharapkan agar menghasilkan peserta didik yang bermutu, yang mempunyai pola pikir dan pola hidup yang selaras dengan perkembangan zaman yang di laluinya (al-Tirmidzi, 1974:137), hal tersebut sesuai dengan Sabda Nabi Muhammad SAW:

Didiklah anak-anakmu, "sesungguhnya mereka adalah mahluk pada zamannya, bukan pada zamanmu” (HR. Tirmidzi).

Pada saat tuntutan zaman semakin ketat, tuntutan akan profesionalisme dalam bekerja menjadi keniscayaan. Dari sinilah, tuntutan akan perlunya profesionalisme dalam bekerja sangat dibutuhkan. Adapun cirri-ciri pokok pekerjaan professional adalah: 1) bahwa pekerjaan itu dipersiapkan melalui proses pendidikan dan latihan secara formal; 2) mendapat pengakuan dari masyarakat; 3) adanya organisasi profesi; 4) mempunyai kode etik sebagai landasan dalam melaksanakan tanggung jawab profesi tersebut. Jadi seorang pendidik yang professional adalah seorang yang memiliki pengetahuan, ketrampilan dan sikap professional yang mampu dan setia mengembangkan dan mengabdikan profesinya.

Dengan demikian strategi pengembangan profesionalisme tenaga pendidik dalam hal ini adalah guru menjadi sangat urgen untuk dilakukan dalam penataan tenaga pendidik dan tenaga kependidikan. Karena 
dengan adanya pengembangan profesionalisme guru akan memberikan kontribusinya yang berarti bagi upaya perbaikan kualitas pendidikan nasional. Berdasarkan latar belakang permasalahan di atas, penulis merumuskan beberapa permasalahan, mengetahui kendala dalam pengembangan tenaga pendidik dilingkungan madrasah, dan strategi yang digunakan sebagai bentuk pengembangan kualitas tenaga pendidik (Guru). Sebagaimana akan di ulas lebih mendalam dalam makalah ini.

\section{Metode Penelitian}

Penelitian ini merupakan penelitian pustaka, dengan menggunakan pendekatan kualitatif yang bertujuan untuk mengeksplorasi, mengelaborasi, dan mensistematisasi arti penting dari suatu fenomena tertentu. Penelitian kualitatif adalah penelitian yang ditujukan untuk mendeskripsikan dan menganalisis fenomena, peristiwa, aktivitas sosial, sikap, kepercayaan, persepsi, pemikiran orang secara individu, kelompok maupun sumber lain yang ada kaitannya dengan permasalahan (Hadi, 2000:9). Penelitian ini bersifat deskriptif-analitis. Penelitian bersifat deskriptif, dalam arti metode yang menggunakan pencarian fakta dan interpretasi yang tepat, dan bersifat analitis dalam arti menguraikan sesuai dengan interpretasi yang tepat, cermat dan terarah (Nasir, 1990:63).

Sebagai penelitian yang bersifat kualitatif dengan menggunakan pendekatan naturalistik, instrumen kunci dalam penelitian ini adalah human instrumen, (Nasution, 1988:55), artinya, penelitilah yang mengumpulkan data, menyajikan data, mereduksi data, memaknai data, 
dan menyimpulkan hasil penelitian. Penelitian kualitatif mempunyai setting natural sebagai sumber data yang langsung dan peneliti adalah kunci instrumen (Djojosuroto, 2000:28). Data dikumpulkan melalui teknik observasi, indepth interview, dialog dan dokumentasi, kemudian diikuti tahapan deskripsi, reduksi, seleksi, pembahasan, analisis dan kesimpulan. Analisis data dilakukan dengan menggunakan metode analisis deskriptif kualitatif (Sugiyono, 2004:12).

\section{Makna, Tujuan, Fungsi, dan Tanggung Jawab Guru}

Secara etimologi guru adalah orang yang pekerjaannya atau mata pencahariannya, profesinya mengajar (Depdikbud, 1996:521). Menurut Bahri (2000:32), bahwa guru adalah semua orang yang berwenang dan bertanggungjawab untuk membimbing dan membina anak didik, baik secara individual maupun klasikal, disekolah maupun diluar sekolah. Sedangkan menurut Darajat (2000:39), guru adalah pendidik professional, karena secara implicit ia telah merelakan dirinya menerima dan memikul sebagian tanggung jawab pendidikan yang terpikul di pundak para orang tua. Dengan demikian seluruh aktivitas-aktivitas yang dijalankan guru harus diperuntukkan untuk kepentingan anak didiknya, yaitu dalam rangka menumbuhkembangkan segenap potensi, baik itu bakat, minat, dan kemampuan-kemampuan lain agar berkembang kearah maksimal. Oleh karena itu, dalam menjalankan tugas, tanggung jawab dan fungsinya, guru harus bisa menciptakan suatu lingkungan pendidikan sebagai wahana yang edukatif, sehingga akal dan kecerdasan anak didik dapat difungsikan dan dikembangkan dengan baik. 
Dalam pendidikan Islam, guru adalah orang yang bertanggung jawab terhadap perkembangan anak didik dengan mengupayakan seluruh potensinya, baik potensi afektif, potensi kognitif, maupun potensi psikomotorik (Nurrudin, 2004:156). Pernyataan tersebut selaras dengan misi pendidikan sebagai sarana transfer ilmu pengetahuan, nilai-nilai dan keterampilan, yang pada dasarnya merupakan kegiatan yang melibatkan guru dan peserta didik. Untuk itu guru mempunyai kekuasaan untuk membentuk dan membangun kepribadian anak didik menjadi seorang yang berguna bagi agama, keluarga, nusa, dan bangsa (Mukmin, 1995:63).

Tugas guru tidaklah hanya sebagai sebuah profesi atau hanya sebatas dinding sekolah, tetapi juga sebagai suatu tugas kemanusiaan dan kemasyarakatan artinya sebagai penghubung antara sekolah dan masyarakat (Roestiyah, 1998:31). Dalam hal ini menurut Roestiyah (1998:32), bahwa guru dalam mendidik anak didik bertugas untuk: 1) menyerahkan kebudayaan kepada anak didik berupa kepandaian, kecakapan, dan pengalaman-pengalaman; 2) membentuk kepribadian anak yang harmonis, sesuai cita-cita dan dasar Negara kita pancasila; 3) menyiapkan anak didik menjadi warga Negara yang baik yang sesuai dengan Undang-undang Pendidikan dan TAP MPR No. 11 Tahun 1993. 4). Sebagai perantara dalam belajar; 5) guru adalah sebagai pembimbing dan penghubung antara sekolah dan masyarakat; 6) sebagai penegak disiplin, administrator, dan manajer yang menjadi contoh peserta didik dalam segala hal, karena guru merupakan sebuah profesi; 7) guru adalah 
perencana kurikulum dan pemimpin (guidance worker) sekaligus sebagai sponsor kegiatan peserta didik.

Dengan melihat point-point diatas maka tugas guru tidaklah ringan, untuk itu profesi guru harus benar-benar berdasarkan panggilan jiwa, sehingga dapat melaksanakan tugas dengan ikhlas. Untuk itu guru harus mendapatkan haknya secara proporsional dengan gaji yang patut diperjuangkan melebihi profesi-profesi lainnya, sehingga keinginan anak didik bukan hanya slogan diatas kertas. Menurut al-Ghazali bahwa tugas pendidik yang utama adalah memperkenalkan, membersihkan, mensucikan, serta membawa hati manusia untuk bertaqarrub kepada Allah SWT.

Adapun Fungsi Guru adalah: 1) sebagai Pendidik: istilah pendidik merujuk pada pembinaan dan pengembangan afeksi peserta didik; 2) sebagai Pengajar: istilah pengajar merujuk pada pembinaan dan pengembangan pengetahuan atau asah otak intelektual; 3) sebagai pelatih atau pembimbing, istilah pelatih meskipun tidak lazim menjadi sebutan untuk seorang guru, merujuk pada pembinaan dan pengembangan ketrampilan atau keprigelan peserta didik (Danim, 2002:15). Ini semua adalah fungsi guru, mengingat tugas guru sebagai suatu profesi menuntut guru untuk mengembangkan profesionalisme diri sesuai perkembangan ilmu pengetahuan dan tekhnologi. Untuk itu dilembaga pendidikan formal ini guru mempunyai tugas pokok dan fungsi yang multi peran, sebagaimana diutarakan diatas.

Adapun Tanggung jawab guru adalah mencerdaskan kehidupan anak didik. Pribadi susila yang cakap adalah yang diharapkan ada pada 
diri anak didik. Untuk melaksanakan tugas tersebut guru harus memiliki komitmen, otonom, dan kepandaian terhadap tugasnya. Maka tanggung jawab guru untuk menggapai kecerdasan adalah mengajar, membimbing, dan melatih, serta mendidik peserta didik (Sahertian, 1994:13). Menurut Hamalik (2003:127), tanggung jawab guru adalah sebagai berikut: 1) menuntut murid-murid belajar; 2) turut serta membina kurikulum; 3) melakukan pembinaan terhadap diri siswa, yang meliputi: kepribadian, watak, dan jasmani; 4) memberikan bimbingan kepada murid; 5) melakukan diagnosis atas kesulitan-kesulitan belajar dan mengadakan penilaian atas kemajuan belajar; 6) menyelenggarakan penelitian; 7) mengenal masyarakat serta turut aktif; 8) menghayati, mengamalkan, dan mengamankan pancasila; 9) turut serta membantu terciptanya kesatuan dan persatuan bangsa dan perdamaian dunia; 10) mensukseskan pembangunan serta meningkatkan peranan professional guru.

\section{Deskripsi Profesionalisme Guru}

Pekerjaan guru adalah mendidik, kecakapan mendidik amat diperlukan agar tujuan pendidikan yang luas itu dapat dicapai semaksimal munkin. Ini berarti kinerja guru harus benar-benar professional. Untuk itu kita harus mengetahui dulu pengertian pengertian profesi dan professional menurut para ahli.

Menurut Hamalik (2002:3), Profesi adalah suatu pernyataan atau janji terbuka, bahwa seseorang akan mengabdikan dirinya kepada suatu jabatan atau pekerjaan dalam arti biasa, karena orang tersebut merasa terpanggil untuk menjabat pekerjaan itu. Dari pengertian tersebut dapat 
dipahami: 1) profesi mengandung arti suatu pernyataan atau janji terbuka yang mengandung norma atau nilai-nilai yang merupakan ekspresi kepribadiannya dan tampak dalam tingkah lakunya; 2) profesi mengandung unsur pengabdian yang bermanfaat bagi orang lain dan masyarakat; 3) profesi merupakan suatu jabatan atau pekerjaan, suatu profesi terkait erat dengan jabatan atau pekerjaan tertentu yang dengan sendirinya menurut keahlian, pengetahuan dan keterampilan tertentu pula.

Sedangkan kata Profesionalisme dalam kosa kata bahasa Indonesia melalui bahsa inggris yaitu (profession) atau bahasa belanda (professie), yang berarti pengakuan atau pernyataan (Bukhori, 1994:36). Dengan demikian, kata profesionalisme berasal dari professional yang berarti suatu pekerjaan yang berkaitan dengan profesi tertentu yang memerlukan keahlian tertentu untuk menjalankannya (Bukhori, 1994:36). Lebih jauh Bukhori (1994:39) menjelaskan profesionalisme, sebagai pandangan yang menganggap bidang pekerjaan sebagai suatu pengabdian melalui keahlian tertentu dan harus diperbaharui secara terus menerus dengan memanfaatkan kemajuan-kemajuan yang terdapat dalam ilmu pengetahuan. Senada dengan pendapat di atas Ahmad Tafsir (2001:174), mengartikan profesionalisme sebagai paham yang mengajarkan bahwa setiap pekerjaan harus dilakukan oleh orang-orang yang profesional.

Profesional guru dalam dunia pendidikan mendapat pengakuan karena tiga hal, yaitu: 1) lapangan kerja keguruan atau kependidikan bukan merupakan suatu lapangan kerja rutin yang dapat dilakukan karena pengulangan-pengulangan atau pembiasaan; 2) lapangan kerja ini 
memerlukan dukungan ilmu atau teori yang akan member konsepsi teoritis ilmu kependidikan dengan cabang-cabangnya; 3) lapangan kerja ini memerlukan waktu pendidikan dan latihan yang lama, berupa pendidikan dasar (basic education) untuk taraf sarjana ditambah dengan pendidikan professional (Roestiyah, 1998:174).

Untuk mendapatkan keprofesionalan dalam profesi guru setidaknya ada beberapa cirri-ciri khusus bagi seseorang tatkala seorang guru itu ingin berkarir secara professional dan cirri-ciri tersebut adalah sebagai berikut: 1) memiliki fungsi dan signifikansi sosial; 2) memiliki keahlian dan ketrampilan tertentu yang diperoleh dengan menggunakan teori dan metode ilmiah; 3) didasarkan atas disiplin ilmu yang jelas dengan diperoleh dalam pendidikan dengan masa tertentu yang cukup lama; 4) aplikasi dan sosialisasi nilai-nilai professional serta memiliki kode etik; 5) kebebasan untuk memberikan judgement dalam memecahkan masalah dalam lingkup kerjanya; 6) memiliki tanggung jawab professional dan otonomi; 7) ada pengakuan dari masyarakat dan imbalan atas layanan profesinya (Sukmadinata, 1997:191).

Adapun persyaratan Untuk menjadikan profesi guru itu menjadi yang professional, maka persyaratannya adalah sebagai berikut: 1) jabatan yang melibatkan kegiatan intelektual dengan menggeluti suatu batang tubuh ilmu yang khusus; 2) jabatan yang memerlukan persiapan professional yang lama dengan latihan dalam jabatan yang berkesinambungan; 3) jabatan yang menjanjikan karier hidup dan keanggotaan yang permanen dengan menentukan baku (standarnya) sendiri; 4) jabatan yang lebih mementingkan layanan diatas keuntungan 
pribadi; 5) jabatan yang mempunyai organisasi professional yang kuat dan terjalin rapat (Soetjipto dan Kosasi, 2000:18).

Menurut Danim (2002:30) untuk melihat profesionalitasnya seorang guru dapat dilihat dari dua prespektif. Pertama, dilihat dari tingkat pendidikan minimal dari latar belakang pendidikan untuk jenjang sekolah tempat seorang guru itu mengajar. Kedua, penguasaan guru terhadap materi bahan ajar, mengelola proses pembelajaran, mengelola siswa, melakukan tugas-tugas bimbingan dan lain-lain, melalui kedua prespektif tersebut dapat diketahui bagaimana kualitas dan kapabelitas seorang guru tersebut.

Mengingat besarnya pengaruh guru terhadap perkembangan anak dalam menanamkan nilai-nilai kehidupan, maka guru dituntut untuk lebih kompeten dalam profesinya, dilihat dari syarat administratif yang dimilikinya apakah sudah sesuai dengan kriteria yang diinginkan, mulai dari segi latar belakang pendidikan formal guru, jenjang pendidikan harus strata satu, berasal dari fakultas keguruan, memberikan subsidi bagi guru yang akan melanjutkan studinya, karena diharapkan nantinya seluruh guru yang ada Lulusan S2. Dengan meningkatnya jenjang pendidikan para guru, maka kinerja para guru akan meningkat. Selain itu pembelajaran dimadrasah akan berjalan lebih efektif dan tujuan madrasah akan mudah tercapai.

\section{Pengembangan Profesionalisme Guru}

Peran professional guru dalam keseluruhan progam pendidikan diwujudkan untuk mencapai tujuan pendidikan yang berupa 
pengembangan siswa secara optimal. Untuk maksud tersebut, maka peran sekolah untuk mendapatkan dan kemudian mengembangkan profesionalisme guru disatu sekolah tertentu sangat besar. Untuk itu dalam mengembangkan profesionalisme guru, madrasah harus mengikuti beberapa langkah-langkah pengembangan.

\section{Perencanaan dan Penentuan Kebutuhan Guru}

Langkah yang harus ditempuh untuk pertama kali oleh setiap organisasi dalam rangka mencapai tujuan yang telah ditentukan adalah penyusunan rencana kebutuhan guru di madrasah. Kebutuhan guru ini penting untuk perbaikan mutu dari madrasah, oleh karenanya perlu diadakan rekrutmen guru dengan menganalisis kebutuhan dalam rangka menetapkan formasi pegawai (kebutuhan guru). Menurut Ibrahim Bafadal (2003:24), terdapat tiga hal yang perlu diketahui dalam rangka menetapkan kebutuhan pegawai, yaitu: 1) jumlah dan jenis pegawai yang ada, yang diketahui dengan inventarisasi pegawai yang ada; 2) beban kerja dan tugas yang ada atau unit-unitnya dalam mengemban misi madrasah; 3) kapasitas kerja pegawai, yang dapat diketahui dengan cara memperkirakan kemampuan pegawai dalam menyelesaikan pekerjaan-pekerjaan tertentu dalam waktu tertentu pula.

Apabila beban kerja dan kapasitas kerja keseluruhan pegawai madrasah diketahui, jumlah pegawai dan jenis pegawai yang diperlukan untuk melaksanakan tugas-tugas bisa diperhitungkan, dengan demikian madrasah bisa menetapkan jumplah dan jenis pegawai yang dibutuhkan dalam madrasah tersebut. Menurut Bafadal (2003:26) ada empat langkah yang ditempuh oleh kepala madrasah dalam melakukan analisis 
kebutuhan guru, yaitu: 1) menetapkan beban kerja sekolah, yaitu dengan mengidentifikasi keseluruhan progam dan tugas yang akan diselesaikan oleh madrasah dalam waktu tertentu dan pada masa mendatang; 2) Menetapkan kapasitas kerja guru, yaitu menetapkan kemampuan maksimal seorang guru dalam menyelesaikan tugas tertentu; 3) Menginventarisasi guru yang ada, yaitu menginventarisasi semua guru yang dimiliki madrasah, baik guru mata pelajaran ataupun guru ekstra kulikuler; 4) Menetapkan jumlah dan jenis guru yang dibutuhkan, dengan cara membandingkan guru yang seharusnya ada untuk menyelesaikan tugas dan progam tersebut dengan jumlah dan jenis guru yang dimiliki oleh Madrasah tersebut.

Dengan demikian, dengan adanya perencanan seperti ini akan memudahkan sekolah untuk meningkatkan kualitasnya, baik itu kualitas dari segi madrasah sendiri maupun kualiatas dari segi tenaga pendidik yang nantinya akan berimplikasi pada peserta didik dengan mengembangnya mutu ini, diyakini akan memberikan kontribusi yang nyata dalam dunia pendidikan.

\section{Rekrutmen dan Penempatan Guru}

Sesuai dengan hasil penelitian diatas yang dilakukan penulis dengan wawancara, maka dalam sistem rekutmen dan penempatan tenaga pendidik (guru) pun tidak asal ambil atau menerima, akan tetapi melalui persyaratan khusus dengan melewati seleksi kemudian orientasi dan penempatanya dalam sistem penerimaannya. Adapun uraiannya adalah sebagai berikut: 


\section{Persyaratan Rekrutmen}

Untuk memiliki guru yang professional sangat tergantung pada kualitas proses rekrutmennya, semakin baik proses rekrutmennya, maka semakin besar pula kemungkinan untuk mendapatkan individu-individu calon guru yang betul-betul professional yang siap secara mandiri melakukan berbagai progam-progam peningkatan mutu pendidikan. Untuk itu setiap Madrasah akan merekrut guru bantu selalu mengadakan seleksi terlebih dahulu. Ini bertujuan untuk mendapatkan guru yang paling menjanjikan dalam melaksanakan tugas-tugas profesionalnya sebagai guru di Madrasah tersebut. Dengan demikian, bagi para calon guru yang akan direkrut harus memenuhi beberapa persyaratan yang ditentukan oleh pihak sekolah, adapun syarat-syarat yang dimaksud antara lain adalah: 1) minimal berpendidikan S1 dari fakultas keguruan atau jika tidak dari fakultas keguruan memiliki akta IV; 2) mengajukan surat lamaran ke Madrasah, dan siap mengikuti tes tertulis dan wawancara; 3) bersedia mematuhi peraturan yang telah ditetapkan oleh pihak madrasah.

Seleksi

Seleksi merupakan langkah yang diambil setelah terlaksananya rekrutmen. Proses seleksi merupakan salah satu fungsi yang terpenting dalam rekrutmen guru, karena diterima tidaknya seorang pelamar yang telah lulus dalam proses rekrutmen, tepat tidaknya penempatan seseorang dalam mengajar mata pelajaran tertentu sangat ditentukan oleh seleksi. Dengan demikian, adanya sistem seleksi akan mampu mengukur tentang tingkat motivasi, komitmen, dan kepribadian pelamar, serta kemampuan dalam mengajar. Karena seorang guru harus memiliki kecintaan terhadap 
anak, mempunyai dedikasi yang tinggi dalam menunaikan tugasny, gesit dalam bertindak, menjukkan kehangatan dalam berkomunikasi, memiliki kesabaran yang memadahi dalam memberikan layanan kepada anak, serta memiliki rasa humor (Bafadal, 2003:32).

Hal seperti diatas perlu dilakukan karena bertujuan untuk mendapatkan calon tenaga pendidik yang benar-benar professional, yang telah memenuhi standar kompetensi yang telah ditentukan, dan yang menentukan beban tugas mengajar guru tersebut.

\section{Orientasi dan Penempatannya}

Bagi guru yang baru memulai menjalankan tugasnya, adanya masa masa orientasi sangat dibutuhkan, Menurut kepala sekolah orientasi adalah suatu kesempatan yang diberikan kepada guru yang baru mulai bekerja untuk mengadakan observasi dan berpartisipasi lansung dengan kegiatankegiatan yang berhubungan dengan tugasnya sebagai guru disekolah itu agar dalam waktu yang relative singkat guru baru tersebut dapat segera mengenal situasi dan kondisi serta kehidupan sekolah dan dapat menyesuaikan diri dengan lingkungan tempat ia bekerja.

Adapun sasaran utama yang dilakukan dalam orientasi guru baru ini adalah: 1) mengenalkan guru baru sistem dan tujuan sekolah, dengan: a) memberikan kesempatan guru baru mempelajari kurikulum dan silabus yang berlaku di madrasah, b) memberikan informasi dan sistem yang diperlukan tentang madrasah tersebut, dan c) mengadakan Tanya jawab dan diskusi baik secara formal maupun informal; 2) membantu guru baru dalam memperkenalkan dan penyesuaian terhadap personil sekolah, adapun hal-hal yang dilakukan untuk ini antara lain: a) memperkenalkan 
kepada semua guru dan pegawai pada suatu pertemuan, b) mengadakan pertemuan ramah tamah disekolah atau diluar sekolah biasanya kalau ada arisan atau pengajian para guru.

\section{Pembinaan dan Pengembangan Profesionalisme Guru}

Pembinaan dan pengembangan profesi guru berarti melakukan perbaikan, meningkatkan kualitas dan peningkatan pelayanan, juga dapat diartikan sebagai upaya membantu guru yang belum matang menjadi matang, yang tidak mampu mengelola sendiri menjadi mampu mengelola sendiri, yang belum memenuhi kualifikasi menjadi memenuhi kualifikasi, yang belum terakreditasi menjadi terakreditasi.

Pengembangan professional guru bertujuan untuk memenuhi tiga kebutuhan, yaitu: 1) kebutuhan sosial untuk meningkatkan kemampuan sistem pendidikan yang efisien dan manusiawi, serta melakukan adaptasi untuk penyusunan kebutuhan-kebutuhan social, yang berkaitan dengan kemasyarakatan guru ditempat mereka berdomisili; 2) kebutuhan untuk menemukan cara-cara dalam membantu staf pendidikan dalam rangka mengembangkan pribadinya secara luas. Dengan demikian guru dapat mengembangkan potensi sosial dan potensi akademik generasi muda dalam interaksinya dengan alam lingkungan sekitar; 3) kebutuhan untuk mengembangkan dan mendorong kehiudpan pribadinya (Danim, 2002:51). Ketiga hal diatas ini sangatlah penting yang menentukan mutu guru-guru yang akan disertakan dalam berbagai kegiatan pelatihan dan penjenjangan jabatan.

Ahmad Samana (1999:31-36) mengemukakan bahwa ada beberapa faktor yang perlu dipertimbangkan dalam mengembangkan 
profesionalisme guru, yaitu: 1) kecakapan guru, yaitu kecakapan komunikasi secara pribadi; 2) kemampuan akal budi manusia mempertanyakan, mengubah, dan mengembangkan unsur-unsur budayanya, salah satunya dengan ilmu pengetahuan dan tekhnologi yang semakin maju; 3) standarisasi keguruan dan penerapannya yang mengalami perkembangan dari waktu kewaktu; 4) pergeseran pola interaksi pendidik dan peserta didik yang selaras dengan taraf kematangan dan perkembangan peserta didik; 4) tujuan pendidikan yang merupakan ultimate goal bagi siswa merupakan tolak ukur dalam refleksi serta realisasi nilai-nilai hidup bagi guru atau tenaga pendidik tersebut (Samana, 1999:36).

Sedangkan menurut Sahertian (1994:69), untuk mengembangkan dan meingkatkan kualitas guru ada tiga progam pengembangan profesi guru yaitu: Pertama, progam pre-service education, yaitu progam yang bertujuan mengadakan layanan pendidikan guru kepada mereka yang berada diluar fakultas keguruan menjadi guru, dan memberikan proteksi dengan mengharuskan pemilikan akta IV bagi mereka yang ingin bekerja dan mengabdi sebagi guru. Kedua, progam in-service education, yaitu layanan yang diberikan oleh lembaga pendidikan guru, bagi mereka yang telah memiliki jabatan melalui pendidikan lanjutan, yang berijazah diploma dapat melanjutkan ke jenjang S1, kemudian dari S1 dapat melanjutkan ke S2, dari S2 dapat melanjutkan ke jenjang S3, dikatakan in-service bila mereka sudah menjabat dan kemudian kuliah lagi. Ketiga, progam in-service training, yaitu adalah progam pelatihan seperti penataran yang bertujuan agar meningkatkan kemampuan guru sesuai 
dengan kemajuan ilmu pengetahuan dan tekhnologi, sehingga para guru memperoleh kualifikasi formal sesuai dengan standar yang dibutuhkan (Sahertian, 1994:69-70).

Secara umum dalam aktivitas pengembangan profesionalitas terus dibina, dengan membentuk struktur organisasi yang khusus menangani pengembangan profesionalisme guru atau yang disebut dengan pembinaan profesi guru (UPP), yang bertugas untuk mengembangkan profesionalisme para guru di madrasah tersebut.

\section{Aktivitas dan Efektifitas Pengembangan Profesionalisme Guru}

Secara umum dapat dikatakan bahwa aktivitas pengembangan profesionalisme guru di Madrasah bisa dilakukan melalui upaya yang harus dilakukan oleh:

\section{Kepala Sekolah}

Dalam rangka pengembangan profesionalitas seorang guru di Madrasah, kepala sekolah memiliki peran yang sangat besar, dan sangat mempengaruhi upaya pengembangan profesionalisme guru tersebut. Adapun usaha yang harus dilakukan dalam rangka pengembangan profesionalisme guru adalah: 1) kepala sekolah meminta gagasan baru kepada guru tentang pelaksanaan tugas yang lebih efektif dan efesien; 2) memberikan kesempatan yang luas terhadap guru untuk mengaktualisasikan diri dalam menghadapi permasalahan; 3) kunjungan kelas, dengan cara masuk kelas-kelas tertentu untuk melihat guru yang sedang mengelola proses pembelajaran; 4) percakapan pribadi, dengan para guru terhadap apa yang diamati; 5) penilaian sendiri, dengan cara menganjurkan guru tersebut melakukan penilaian terhadap dirinya 
sendiri; 6) memberikan motivasi, dengan memberikan reward atau pujian,

\section{Pembinaan Profesi Guru (PPP)}

Urusan pembinaan profesi di madrasah, mempunyai perencanaan dan progam kerja kedepan, yang merupakan titik tolak bagi pelaksanaan pengembangan profesionalisme guru dan juga pemantau kearah mana kegiatan harus diarahkan. Dengan rencana tersebut maka landasan untuk mengadakan penilaian dikemudian hari bisa diukur lewat tingkat efektifitasnya dan efesiensinya yang terbagi menjadi dua progam yaitu:

Progam jangka pendek, yaitu terwujudnya perangkat kinerja guru dan peningkatan perangkat kinerja guru, sedangkan yang dimaksud perangkat kinerja guru adalah buku kerja guru I yang berisi (Kurikulum Pendidikan, silabus RPP), dan buku kerja guru II berisi (kalender pendidikan, progam tahunan, progam semester, progam harian), dan buku kerja guru III, berisi (daftar hadir siswa, soal ulangan harian, daftar nilai, analisis hasil ujian, daftar pegangan guru dan lain sebagainya). Adapun yang dimaksud dengan peningkatan kinerja guru adalah melalui pelatihan-pelatihan atau penataran, misalnya: pelatihan khusus desain pembelajaran, kemahiran berbahasa, pelatihan pembelajaran multmedia dan lain sebagainya.

Progam Jangka Panjang: yaitu rencana yang ingin dicapai oleh Madrasah untuk masa yang akan datang dan memakan waktu yang lama, akan tetapi pada pelaksanaannya sudah dimulai dari sekarang. Adapun progamnya adalah: 1) aplikasi komputer atau kemampuan operasional komputer bagi para guru-guru dan kepemilikannya; 2) kursus Bahasa 
Asing; 3) studi banding; 4) achievement motivation training atau disingkat menjadi AMT; 5) menjadikan guru menjadi seorang TOT dari pada pelatihan AMT yang pernah dipelajarinya yaitu training of trainers; 6) mensituasikan pola pembelajaran aktif kerja kelompok; 7) pembentukan kelompok studi atau team work.

Melalui Tugas belajar (Studi Lanjut)

Dalam upaya pengembangan professional para guru Madrasah dan meningkatkan kualitas penyelenggaraan pendidikan adalah dengan tugas belajar (in-service education) dilakukan dengan memberi keringanan beban tugas mengajar bagi yang guru yang bersangkutan ketika sedang studi lanjut, sedangkan biaya selama studi diberi pinjaman oleh pihak sekolah. Untuk progam kedepan biaya tugas belajar akan ditanggung oleh madrasah atau akan mendapatkan rekomendasi beasiswa dari sekolah.

\section{Profesionalisme Guru Dalam Memperbaiki Mutu Pembelajaran}

Dalam meningkatkan profesionalisme guru dalam memperbaiki mutu pembelajaran di Madrasah, ada tiga hal yang diwujudkan yaitu: 1) diharuskannya siswa dan guru memiliki akses kepada teknologi digital dan internet dalam kelas, sekolah, dan lembaga pendidikan guru; 2) menyediakan materi yang berkualitas, bermakna, dan dukungan kultural bagi siswa dan guru; dan 3) serta mewajibkan guru untuk memiliki pengetahuan dan ketrampilan dalam menggunakan alat-alat dan sumbersumber digital untuk membantu siswa agar mencapai standar akademik. Sejalan dengan pesatnya perkembangan Teknologi Informasi, maka telah 
terjadi pergeseran pandangan tentang pembelajaran baik di kelas maupun di luar kelas (Sudirman, 2008:19).

Dalam pandangan tradisional di masa lalu (dan masih ada pada masa sekarang), proses pembelajaran dipandang sebagai: 1) sesuatu yang sulit dan berat, karena proses pembelajaran masih menekankan pada kemampuan tenaga pendidik dan stagnan pada SK dan KD yang diberikan tanpa ada pengemabangan, secara otomatis beban pembelajaran menjadi berat dan melelahkan; 2) upaya mengisi kekurangan siswa, dengan hanya berpusat pada guru, dengan kata lain pusat transformasi ilmu didapat hanya lewat gurunya saja; 3) satu proses transfer dan penerimaan informasi; 4) proses individual atau soliter; 5) kegiatan yang dilakukan dengan menjabarkan materi pelajaran kepada satuan-satuan kecil dan terisolasi; 6) suatu proses linear (Cahyo, 2013:18; Muchit, 2008:1).

Sejalan dengan perkembangan Teknologi Informasi telah terjadi perubahan pandangan mengenai pembelajaran yaitu pembelajaran sebagai: 1) proses alami; 2) proses sosial; 3) proses aktif dan pasif; 4) proses linear dan atau tidak linear; 5) proses yang berlangsung integratif dan kontekstual; 6) aktivitas yang berbasis pada model kekuatan, kecakapan, minat, dan kulktur siswa; 7) aktivitas yang dinilai berdasarkan pemenuhan tugas, perolehan hasil, dan pemecahan masalah nyata baik individual maupun kelompok (Hardini, Puspitasari, 2012:144147) .

Hal itu telah mengubah peran guru dan peran siswa dalam pembelajaran, adapun perubahan itu dapat dijelaskan sebagai berikut: 1) 
peran guru telah berubah dari: a) sebagai penyampai pengetahuan, sumber utama informasi, ahli materi, dan sumber segala jawaban, menjadi fasilitator pembelajaran, pelatih, kolaborator, navigator pengetahuan, dan mitra belajar, b) sebagai pengendali dan pengarah semua aspek pembelajaran, menjadi pemberi alternatif dan tanggung jawab kepada setiap siswa dalam proses pembelajaran; 2) peran siswa telah berubah dari: a) penerima informasi yang pasif menjadi partisipan aktif, b) mengungkapkan kembali pengetahuan menjadi menghasilkan dan berbagai pengetahuan, c) pembelajaran sebagai aktiivitas individual (soliter) menjadi pembelajaran berkolaboratif dengan siswa lain (Budiningsih, 2005:58). Lingkungan pembelajaran yang di masa lalu berpusat pada guru telah bergesar menjadi berpusat pada siswa. Secara rinci dapat digambarkan pada Tabel 1.

Tabel 1. Perubahan Paradigma Lingkungan Pembelajaran

\begin{tabular}{|c|c|c|}
\hline Lingkungan & Berpusat pada guru & Berpusat pada siswa \\
\hline Aktivitas kelas & $\begin{array}{l}\text { Guru sebagai sentral dan } \\
\text { bersifat didaktis }\end{array}$ & $\begin{array}{l}\text { Siswa sebagai sentral dan } \\
\text { bersifat interaktif }\end{array}$ \\
\hline Peran guru & $\begin{array}{l}\text { Menyampaikan fakta-fakta, } \\
\text { guru sebagai ahli }\end{array}$ & $\begin{array}{l}\text { Kolaboratif, kadang- } \\
\text { kadang siswa sebagai akhli }\end{array}$ \\
\hline Penekanan pengajaran & Mengingat fakta-fakta & $\begin{array}{l}\text { Hubungan antara informasi } \\
\text { dan temuan }\end{array}$ \\
\hline Konsep pengetahuan & $\begin{array}{l}\text { Akumulasi fakta secara } \\
\text { kuantitas }\end{array}$ & Transformasi fakta-fakta \\
\hline $\begin{array}{l}\text { Penampilan } \\
\text { keberhasilan }\end{array}$ & Penilaian acuan norma & $\begin{array}{l}\text { Kuantitas pemahaman, } \\
\text { penilaian acuan patokan }\end{array}$ \\
\hline Penilaian & Soal-soal pilihan berganda & $\begin{array}{l}\text { Protofolio, pemecahan } \\
\text { masalah, dan penampilan }\end{array}$ \\
\hline Penggunaan teknologi & Latihan dan praktek & $\begin{array}{l}\text { Komunikasi, akses, } \\
\text { kolaborasi, ekspresi }\end{array}$ \\
\hline
\end{tabular}

Semua hal diatas tidak akan terjadi dengan sendirinya karena setiap siswa memiliki kondisi yang berbeda antara satu dengan lainnya. 
Siswa memerlukan bimbingan baik dari guru maupun dari orang tuanya dalam melakukan proses pembelajaran dengan dukungan Teknologi Informasi. Dalam kaitan ini guru memegang peran yang amat penting dan harus menguasai seluk beluk Teknologi Informasi dan yang lebih penting lagi adalah kemampuan memfasilitasi pembelajaran anak secara efektif. Peran guru sebagai pemberi informasi harus bergeser menjadi manajer pembelajaran dengan sejumlah peran-peran tertentu, karena guru bukan satu-satunya sumber informasi melainkan hanya salah satu sumber informasi.

Siswa-siswa dalam pembejaran tradisional dipandang sebagai "kertas kosong" yang dapat digoresi informasi oleh guru yang menggunakan metode didaktik dalam menyampaikan informasi kepada siswanya. Namun, dalam pembelajaran modern, siswa dipandang sebagai pemikir-pemikir yang dapat memunculkan teori-teori tentang dirinya (Budiningsih, 2005:63). Menurut Louis dan Gerstmer (2005:45-55) di masa-masa mendatang peran guru mengalami perluasan, yaitu: 1) sebagai pelatih (coaches), yang memberikan peluang bagi siswa untuk mengembangkan cara-cara pembelajarannya; 2) sebagai konselor, yang menciptakan satu situasi interaksi belajar-mengajar; 3) sebagai manajer pembelajaran, yang memiliki kemandirian dan otonomi yang seluasluasnya dalam mengelola keseluruhan kegiatan belajar-mengajar; 4) sebagai partisipan, yang tidak hanya berperilaku mengajar akan tetapi juga berperilaku belajar dari interaksinya dengan siswa; 5) sebagai pemimpin, yang mampu menggerakkan orang lain untuk mewujudkan perilaku menuju tujuan bersama; 6) sebagai pembelajar, yang senantiasa 
menyegarkan kompetensinya serta meningkatkan kualitas profesionalnya; 7) sebagai pengarang, yang kreatif dan inovatif menghasilkan berbagai karya yang akan digunakan untuk melaksanakan tugas-tugas profesionalnya (Louis, Gerstmer, 2005:45-55).

Guru merupakan kunci dalam peningkatan mutu pendidikan, dan guru disini berada pada posisi yang sangat strategis bagi seluruh upaya reformasi pendidikan yang berorientasi pada pencapaian kualitas murid dan persekolahan. Adapun upaya yang dilakukan dalam peningkatan kualitas pendidikan dalam sebuah sistem persekolahan akan menjadi tidak berarti jika tidak disertai oleh adanya guru yang professional (Surya, 2000:1-2). Dengan demikian, keprofesionalan seorang guru dapat diukur dari segi aktifitasnya dengan lingkup teknologi informasi yang merupakan sumber kreativitas dan pengembangan terhadap pendidikan yang sedang dilangsungkan. Oleh karena itu dalam mengembangkan guru yang professional, seorang guru tidak hanya dituntut untuk mempertebal kemampuan secara disipliner, tetapi juga mempunyai kualitas yang interdisipliner. melalui pendekatan bersama untuk semua dan pendekatan berbeda untuk disiplin spesialis yang berbeda (Ashrof, 1993:5).

\section{Faktor-faktor Pengembangan Profesionalisme Guru}

Bila ditelusuri tentang pelaksanaan usaha pengembangan profesionalitas guru di madrasah, akan ditemukan beberapa faktor pendukung, diantranya: 1) memiliki kerjasama antar instansi terkait; 2) memiliki semangat dan loyalitas yang tinggi dalam mengembangkan tugasnya; 3) menerima setiap masukan dan saran yang diberikan oleh para supervisor 
dan pihak lain; 4) mengembangkan kualitas keprofesionalannya yang mana hal ini merupakan hal yang sangat baik bagi dirinya atau sekolah tempat guru tersebut mengajar.

Adapun faktor penghambat yang dihadapi oleh madrasah dalam meningkatkan mutu tenaga pendidik dalam hal ini adalah guru, antara lain: 1) keterbatasan sekolah dalam menyediakan dana atau keungan sebagai penunjang usaha pengembangan profesionalisme guru; 2) kurang aktif dan sportifnya guru dalam menjalan aktifitas profesinya sebagai seorang tenaga pendidik; 3) waktu yang dimiliki sangat kurang, hal ini dikarenakan guru selain bertugas di madrasah juga sebagai anggota masyarakat dimana guru tersebut tinggal; 4) kesiapan untuk menerima sesuatu hal yang baru sangat rendah.

Dengan adanya progam pengembangan profesionalisme guru ini diharapkan para guru madrasah, lebih efektif dan efesien dalam menjalankan tugasnya serta sebagai tenaga edukatif dan bisa membawa perubahan pada anak didiknya menuju kepada kemajuan sesuai dengan tujuan pendidikan yang diharapkan.

\section{Simpulan}

Pengembangan professional guru berarti suatu pembinaan yang dilakukan secara terus-menerus untuk meningkatkan kualitas dan pengembangan karir tenaga professional guru. Ada tiga hal yang bisa di lakukan madrasah dalam mewujudkan Profesionalisme guru dalam mengajar. dan ketiga hal diatas yaitu, progam pre-service education, progam in-service education, dan progam in-service training. Dengan 
program tersebut guru semakin berkembang dengan baik potensi profesi dan kompetensi tenaga pendidiknya, sehingga dalam kegiatan pembelajaran yang dilakukan dapat lebih efektif untuk mencapai tujuan yang diharapkan, yang didukung dengan strategi pengembangan professional guru melalui upaya kepala sekolah, UPP (urusan pembinaan profesi) dan studi lanjut bagi para guru, yang merupakan progam dari sekolah tersebut.

\section{Daftar Pustaka}

Al-Tirmidzi. (1974). Sunan At-Tirmidzi; Al-Jami'ah As-Shahihah, Madinah Munawaroh: Maktabah As-Sahifah,

Ashrof, A. (1993). Horizon Baru Pendidikan Islam. Terj. Sari Siregar, Yogyakarta: Pustaka Firdaus.

Bafadal, I. (2003). Peningkatan Profesional Guru Sekolah Dasar; Dalam Kerangka Manajemen Peningkatan Mutu Berbasis Sekolah. Jakarta: Bumi Aksara.

Djamarah, S. B. (2000). Guru Dan Anak Didik. Jakarta: Rineka Cipta. Budiningsih, A. (2005). Belajar dan Pembelajaran. Jakarta: Rineka Cipta.

Bukhori, M. (1994). Pendidikan Dalam Pembangunan. Yogyakarta: Tiara Wacana.

Cahyo, A. N. (2013). Panduan Aplikasi teori-teori Belajar Mengajar Aktual dan Terpopuler. Yogyakarta: DIVA Press.

Danim, S. (2002). Inovasi Pendidikan: Dalam Upaya Peningkatan Profesionalisme Tenaga Kependidikan, Bandung: Pustaka Setia.

Darajat, Z. (2000). Ilmu Pendidikan Islam. Jakarta: Bumi Aksara.

Djojosuroto, K. (2000). Prinsip-prinsip Dasar Penelitian Bahasa dan Sastra, Bandung: Yayasan Nuansa Cendikia.

Hadi, S. (2000). Metodologi Research. Yogyakarta: Fakultas Psikologi UGM.

Hamalik, O. (2002). Pendidikan Guru: Berdasarkan Pendekatan Kompetensi. Jakarta: Bumi Aksara.

Hamalik, O. (2003). Proses Belajar Mengajar. Jakarta: Bumi Aksara. 
Hardini, I. (2012). Strategi Pembelajaran Terpadu: Teori, Konsep, dan Implementasi. Yogyakarta: Familia Group Relasi Inti Media.

Muchith, S. (2008). Pembelajaran Kontekstual. Semarang: Rasail Media Grup.

Mukmin. (1995). Profil Guru yang Baik Dalam Perspektif Pendidikan Islam. Yogyakarta: IAIN Sunan Kalijaga.

Nasir, M. (1990). Metode Penelitian, Jakarta: Graha Indonesia

Nasution, D. (1998). Metode Penelitian Naturalistik Kualitatif. Bandung: Tarsito.

Nasution, H. (1991). Pembaharuan dalam Islam: Sejarah Pemikiran dan Gerakan. Jakarta: Bulan Bintang.

Nurrudin, M. (2004). Kiat Menjadai Guru Profesional. Yogyakarta: Prisma Sophie.

Roestiyah. (1998). Didaktik Metodik. Jakarta: Bumi Aksara.

Sahertian, P. A. (1994). Profil Pendidik Profesional, Yogyakarta: Andi Ofset.

Samana, A. (1999). Profesionalisme Keguruan, Jakarta: Rineka Cipta.

Soetjipto \& Kosasi, R. (2000). Profesi Keguruan. Jakarta: Rineka Cipta.

Sudirman, A. (2008). Media Pendidikan, Pengertian, Pengembangan dan Pemanfaatannya. Jakarta: Raja Grafindo Persada.

Sukmadinata, N. S. (1997). Pengembangan Kurikulum: Teori dan Praktek. Bandung: Remaja Rosdakarya.

Surya, M. (2000). Aspirasi Peningkatan Kemampuan Professional dan Kesejahteraan Guru. Jurnal Pendidikan dan Kebudayaan. No. 21 Tahun ke 5, Januari.

Tafsir, A. (2001). Ilmu Pendidikan Islam dalam Prespektif Pendidikan Islam. Bandung: Remaja Rosdakarya.

Usman. (1992). Menjadi Guru Profesional. Bandung: Remaja Rosdakarya. 